\title{
IMPACT OF PESTICIDE TOLERANT SOIL BACTERIA ON DISEASE CONTROL, PLANT GROWTH PROMOTION AND SYSTEMIC RESISTANCE IN COWPEA
}

\author{
Anuradha BANDOPADHYAY (1) ${ }^{*}$, Tina ROY ${ }^{2}$, Nirmalendu DAS (D) 3 \\ ${ }^{1}$ Mycology Laboratory, Department of Botany, Barasat Government College, \\ Barasat, Kolkata 700124, West Bengal, India \\ ${ }^{2}$ Department of Botany, University of Gour Banga, Malda, West Bengal, India \\ ${ }^{3}$ Microbiology Laboratory, Department of Botany, Barasat Government College, \\ Barasat, Kolkata 700124, West Bengal, India
}

Received 31 October 2020; accepted 08 December 2020

\begin{abstract}
Highlights
D Methomyl, imidacloprid and carbendazim tolerant strains of Bacillus cereus, B. safensis, Pseudomonas donghuensis and P. aeruginosa have plant growth promoting and antagonistic traits.

- Pesticide tolerant rhizobacteria showed in vitro antagonistic activity against pathogen Macrophomina phaseolina.

- PGPRs controlled Macrophomina diseases and promoted growth in cowpea in a toxic environment.

D PGPRs triggered induced systemic resistance and enhanced enzyme activity of PAL, PO, PPO and chitinase after pathogen challenge inoculation in host plant.

- These PGPRs proved prospective for disease control, plant growth promotion and decontamination of pesticide and heavy metal contaminated soil for sustainable eco-friendly agriculture.
\end{abstract}

\begin{abstract}
Cowpea, an annual legume, suffers from several disease symptoms caused by Macrophomina phaseolina. Rhizobacteria isolated from pesticide infested soil, identified by blast analysis as Bacillus cereus, Bacillus safensis, Pseudomonas donghuensis and Pseudomonas aeruginosa ascertained tolerant to at least $0.1 \%$ pesticides viz. methomyl, imidacloprid and carbendazim. In vitro antagonism against pathogen exhibited maximum by $P$. aeruginosa $63 \%$. All rhizobacteria were bestowed with attributes responsible for pathogen control and plant growth promotion. Field evaluation resulted highest $75 \%$ disease control, enhancement of length, nodule counts, biomass or yield per plant by P. aeruginosa. All rhizobacteria induced systemic resistance in cowpea under challenged inoculation with pathogen by augmenting defensive enzyme production. Highest Phenylalanine Ammonia Lyase activity was expressed in P. aeruginosa treated plants $1.02 \mu \mathrm{Moles} / \mathrm{ml} / \mathrm{min}$, Polyphenol Oxidase by P. donghuensis $1.39 \mu$ Moles $/ \mathrm{ml} / \mathrm{min}$, Chitinase by B. cereus $0.745 \mu \mathrm{Moles} / \mathrm{ml} / \mathrm{min}$ and 400 percent relative activity of Peroxidase by $P$. aeruginosa. The rhizobacteria were prospective for plant disease control, growth promotion and as immunity boosters in pesticide and heavy metal infested toxic environment.
\end{abstract}

Keywords: soil contamination, pesticide tolerant rhizobacteria, disease control, plant growth, systemic resistance.

\section{Introduction}

Cowpea (Vigna unguiculata (L.) Walp.), an annual legume, is among the earliest known human food sources (Chevalier, 1964) and supposedly the principal ancient pulse crop of India. National productivity of the crop is $683 \mathrm{~kg}$ per ha (Singh et al., 2012) and West Bengal share about 3\% of India's total production along with other species of Vigna. Cowpea is commonly consumed as pulse crop, green vegetables, fodder and green manure. The plant fixes atmospheric nitrogen @ of 56 kg per ha in soil, with root nodule inhabiting symbiotic bacteria (Ahlawat \& Shivkumar, 2005) as well as enriches soil microbial population. As food legume, it is rich dietary source of 24.8 percent protein, 63.6 percent carbohydrate, 1.9 percent fat, 6.3 percent fibre, 0.00074 percent thiamine, 0.00042 percent riboflavin and 0.00281 percent niacin (Davis et al., 2000).

*Corresponding author. E-mail: anuradhabandopadhyay43@gmail.com 
But the crop undergoes biological bottle neck of low productivity. The fungal pathogen, Macrophomina phaseolina (Tassi.) Goid. incites several disease viz. seed rot, seedling damping off, charcoal rot, dry root rot, leaf and stem blight from all stages of crop growth. The yield loss is $10-80 \%$ (Tiwari \& Shivare, 2016). Use of chemical fungicides like thiram, mancozeb, tebuconazole or carbendazim (Benzimidazole), though diminish the disease incidence but pose several challenges to the crop. The micro sclerotia of Macrophomina persist in soil and risks chance about resurgence of pesticide resistant strains of the pathogen. Moreover, extreme usage of these pesticides may lead to ineffectiveness of beneficial plant rhizosphere associated microbiome and loss of soil fertility. The pesticides proved deleterious on growth of Rhizobium, affecting the nod genes concerned in the nodulation process and nitrogenase activity in the leguminous crop (Niewiadomska \& Klama, 2005; Shahid \& Khan, 2017). Intemperance pesticides may be poisonous to the food crop, beneficial soil fauna, microbiota as well as affecting human and veterinary health (Carvalho, 2017; Heard et al., 2017; Wu et al., 2018).

Therefore, tactics of natural control with pesticide tolerant rhizosphere microorganisms is effectual in crop protection, plant vigor augmentation and soil bioremediation for sustainable agriculture. Microbial growth pattern, simple genetic organization, presence of extra-chromosomal genetic material, high adaptability, elevated metabolic activity with high enzymatic action and nutritional versatility are prime attributes which can be utilized for effective bioremediation practices (Cavalier-Smith, 2005). Among them, Plant growth promoting rhizobacteria (PGPR) have great potential for disease control as well as growth enhancement through diverse mechanism and have been reckoned important in sustainable agriculture and environmental health (Kloepper, 1993; Liu et al., 2017). PGPRs improve plant growth directly through production of plant growth regulators (PGRs), siderophores, ACC deaminase, fixation of atmospheric nitrogen and solubilization of insoluble phosphate. Indirect beneficial influence on host may be through suppression of deleterious root colonizing microorganisms including plant pathogens through antibiosis by production of antimicrobial substances or lytic enzymes, competition for food and shelter, or niche exclusion.

Induced systemic resistance of host plants against pathogen is a prevalent phenomenon that has been extensively investigated for its potential use in plant protection. PGPRs can repress diseases by inducing systemic resistance (ISR) in the plants against foliar and root pathogens. The usually non specific character of induced resistance confers an immunity boost in the stage of basal resistance against numerous pathogens simultaneously, which is advantageous under natural conditions where compound pathogens may be present (Van Loon et al., 1998). Synthesis of defense chemicals in host are improved by PGPR triggered ISR upon challenging with pathogen. Expression of defense related enzymes viz., Phenylalanine Ammonia
Lyase (PAL), Peroxidase (PO) and Polyphenol Oxidase (PPO) induce increment of total lignin and phenolics in plant tissues (Karthikeyan et al., 2005). PO participates in defensive activities due to phenolic oxidation and lignification in host tissues against pathogens. Similarly, PAL plays a defensive role and acts as precursor compound in the biosynthesis of several flavonoids and lignins. Chitin is a principal fungal cell wall component which is also degraded by chitinolytic bacteria. Recently, use of ISR mechanism to suppress fungal pathogens has received increasing attention (Akram et al., 2013; Fatima \& Anjum, 2017). Concurrently, PGPRs with production of ACC Deaminase help in metal and other chemo-toxin detoxification, alleviation or tolerance improvement against abiotic stresses like drought, high salinity, high pesticide loads in plants (Ngumbi \& Kloepper, 2016; Saikia et al., 2018) as well as play role in bioremediation of contaminated soils (Jiang et al., 2008).

Import of foreign PGPR strains in heavily pesticide infested soil may not survive or express their beneficial traits. But some microorganisms develop tolerance after a long term exposure to pesticides, using them as substrates for nutrient and energy subsequently degrading into non toxic residues. These microbes can successfully be used for bioremediation of pesticide contaminated soils (Khan et al., 2009). On the other hand, these microbes may have disease suppressive and plant growth promoting (PGP) attributes and can be used in soil remediation (Shahgoli \& Ahangar, 2014) along with plant growth enhancement with easy adaptation in toxic micro environment in soil. Several PGPR genera such as Bacillus, Achromobacter, Pseudomonas, Mesohizobium, Alcaligenes, Sphingomonas, and Ralstonia, have been reported for conversion of pollutants including antibiotics and toxic metals into non toxic compounds, thus featuring bioremediation of the environment (Sobariu et al., 2017).

The present study endeavors to investigate the effect of some pesticide tolerant rhizobacteria on Macrophomina disease control, growth improvement and yield of pulse crop cowpea in pesticide infested farmer's field. The study also scrutinizes the effect of bio-agents on immunity system inducing systemic resistance in host plant. Therefore, efficacy of pesticide resistant rhizobacteria as PGPR in agrochemical and heavy metal contaminated soil as well as bioremediation of toxic environment is inspected in this article.

\section{Materials and methods}

\subsection{Media and chemicals}

The culture media, including Nutrient Broth (NB), Nutrient Agar (NA), Potato Dextrose Agar (PDA) were purchased from HiMedia, India. Mineral salt (MS) medium contained ( $\mathrm{g} / \mathrm{L}$ distilled water) $\mathrm{NaCl} 1.0,(\mathrm{NH} 4)_{2} \mathrm{SO}_{4} 1.0$, $\mathrm{MgSO}_{4} \cdot 7 \mathrm{H}_{2} \mathrm{O} 0.05, \mathrm{~K}_{2} \mathrm{HPO}_{4}$ 0.5, pH 7.0 (Roy \& Das, 2017). Commercial Methomyl (Lannate ${ }^{\circ}$ ), Carbendazim (Superstin) and Imidacloprid (Compact) were used. All 
other reagents and chemicals used were of analytical grade.

\subsection{Isolation and identification of pesticide tolerant rhizobacteria}

All the bacteria were isolated from pesticide infested rhizospheric soil from farmer's field of different districts of West Bengal, India. Serial dilution plate technique (Johnson \& Curl, 1972) was followed using MS medium supplemented with $0.01 \%$ pesticide and incubation at $37{ }^{\circ} \mathrm{C}$ for $24 \mathrm{hr}$ for microbial isolation. Optimum pesticide tolerance of these strains were tested in the presence of different concentration of methomyl, carbendazim and imidacloprid in nutrient broth with or without $2 \%$ agar (Bandopadhyay et al., 2018). Selected rhizobacteria were identified by $16 \mathrm{~S}$ rDNA sequences obtained from PCR products subjected to BLAST analyses using the on line server of NCBI (http://www.ncbi.nlm.nih.gov/blast).

The selected isolates were primarily screened for antagonistic and plant growth promoting traits viz. production of volatile and non volatile compounds, HCN, cell wall degrading enzymes (CWDE) like endoglucanase, pectinase and chitinase, Indole-3 Acetic Acid (IAA), siderophore, nitrogen fixation and solubilization of inorganic phosphate in presence or absence of pesticide (Bandopadhyay et al., 2018).

\subsection{The pathogen}

The fungal pathogenic strain was isolated from diseased sample of a local variety of cowpea plant. Pathogenicity of the isolate was confirmed against Triguna variety of cowpea. The pathogenic strain was identified by Internal Transcribed Spacer (ITS) sequencing subjected for BLAST analysis in NCBI.

\subsection{In vitro antagonistic activity of rhizobacteria}

In vitro evaluation of selected rhizobacteria for antagonistic activity against pathogen was conducted following dual culture plate technique using PDA and NA (1:1) mixed media (Bandopadhyay et al., 2006).

\subsection{Evaluation of rhizobacteria for disease control and plant growth promotion in field}

The rhizobacteria were evaluated for disease control and plant growth promotion in long term agrochemical and heavy metal contaminated farmer's field after successful trial in green house (Bandopadhyay et al., 2018). Cowpea variety Triguna was used for the experiment.

Nine treatments with 3 replications in micro-plots (size $1.5 \times 1 \mathrm{~m}$ ) were planned in RBD for the period of kharif season between early May to July, temperature prevailing between $30-35^{\circ} \mathrm{C}$. Control treatments having nonamended plots or only Carboxymethyl cellulose (CMC) treated seeds were kept. Only pathogen containing plots were also included in the design. All the plots were made sick with $50 \mathrm{~g}$ of pathogen inoculums grown in sand maize meal medium. The rhizobacteria were grown for 72 hours at $30 \pm 2{ }^{\circ} \mathrm{C}$ with intermittent shaking. All rhizobacteria were applied singly with population @ 20X106 $\mathrm{cfu} \mathrm{ml}^{-1}$ of culture media. Bio-filming was done by mixing $20 \mathrm{~g}$ of seeds, $50 \mathrm{ml}$ of bacterial slurry, $2.5 \mathrm{~g}$ each of CMC and molasses for better adherence and nutrient supply. After two weeks, seedlings were thinned out to keep plants at a distance of $10 \mathrm{~cm}$ apart. Disease counts were taken at 7 days interval till 35 days. Five plants per plot were taken for measurement of root/shoot length, biomass and nodule count in each plant at 15 days interval. Number of pods and total weight of pods per plant were counted after harvest.

For calculating bio-control efficacy (BE) of bacteria against Macrophomina isolate causing seed rot, seedling damping off, charcoal rot, dry root rot, leaf and stem blight in cow pea, the disease severity was recorded based on score $0-9$, depending on both underground and above ground symptoms as follows: 0 -Healthy plant without any visible symptom, 1-pre emergence damping off, 2post emergence damping off of seedlings, 3-discoloration of root about 5\%,4-discoloration of root system above 25\%, 5-discoloration of stem at soil line, 6-Cankers seen on stem spreading upward, 7-discoloration of whole root systems as well as epicotyls with lower leaves wilting, 8Roots rot, leaves wilt and drop from plant. Sclerotia seen in affected tissue, 9-Dead plants.

Percent Bio-control efficacy $(\mathrm{BE})=[($ Disease incidence of Macrophomina treated control - Disease incidence of bacteria treated plants)/ Disease incidence of control] $\times 100$.

Assessment of charcoal rot and root rot disease incidence on cowpea plants were calculated. Percent (\%) disease incidence using the following formula:

$$
\begin{aligned}
& \text { Percent (\%) Disease Incidence }(\mathrm{DI})= \\
& \frac{\text { Number of infected plants Incidence }}{\text { Total number of plants observed }} \times 100 \text {. }
\end{aligned}
$$

Disease assessment was recorded from an average of 15 plants in each treatment with a replica in triplicates including healthy and disease control.

\subsection{Induced systemic resistance in host plants}

To study the effect of rhizobacteria on induced systemic resistance in host plant, bacterial inoculums were soil drenched after thirty days of plant growth, following application of fungal pathogen after 7 days.

Leaf samples $(1 \mathrm{~g})$ were collected from each treatment after challenged inoculation with the pathogen. Then samples from each of the treatments were collected at an interval of $24 \mathrm{~h}$ up to $120 \mathrm{~h}$. The samples were stored at $-20^{\circ} \mathrm{C}$ for enzymatic study. Total protein content of leaf tissues were measured by the method of Bradford (1976) with slight modifications. Defense related enzyme viz. Phenyl Alanine Ammonia Lyase (PAL), Polyphenol Oxidase (PPO), Peroxidase (PO) and Chitinase were estimated. 


\subsubsection{Assay of Phenylalanine ammonia-lyase (EC} 4.3.1.24)

Phenylalanine ammonia-lyase, an enzyme catalyzes the reaction converting L-phenylalanine to Trans-cinnamic acid and ammonia. This assay was performed following the modified method of Ambalavanan and Selvaraj (2013).

\subsubsection{Assay of Polyphenol oxidase (EC 1.14.18.1)}

Polyphenol oxidases are group of copper containing enzymes present widely in nature. They catalyze the aerobic oxidation of certain phenolic substrates. This assay was performed following the method of Boeckx et al. (2015).

\subsubsection{Assay of Peroxidase (EC 1.11.1.7)}

Peroxidase catalyzes the oxidation of many organic compounds like phenol, aromatic amines, hydroquinone etc. For the assay of peroxidase, guaiacol is used as substrate. This assay was conducted according to Pütter (1974) with modification.

\subsubsection{Assay of Chitinase (EC 3.2.1.14)}

Chitinase enzyme was assayed following the method of Yan and Fong (2015). Enzymatic hydrolysis of colloidal chitin by chitinase resulted in release of free $\mathrm{N}$-acetylglucosamine (NAG) which was detected using di-nitro salicylic acid (DNSA) reagent.

\subsection{Statistical analysis}

All the data presented here are mean of three replication of each experiment. GraphPad Prism software (v.5.0) was used for comparison with control groups.

\section{Results and discussion}

\subsection{Identification and characterization of micro- bioagents}

Rhizobacterial isolates Tn-1, Tn-4, D1, and Tn 6 were pesticide tolerant at different concentrations (Bandopadhyay et al., 2018) apart from Bacillus cereus (NCIM 5557) and Bacillus safensis (NCIM 5558) (Roy et al., 2018) which were considered as reference strains. NCBI BLAST analysis identified Tn-1 as Pseudomonas donghuensis (MH145358.1), Tn-4 as Bacillus cereus (MK940251), Tn 6 as Pseudomonas aeruginosa (MH084956.1) and D1 as B. cereus (KY229915.1). The fungal pathogen $\mathrm{m} 2$ were identified as Macrophomina phaseolina (MK940251).

All the bacterial isolates used in the current study showed negative result in blood agar medium and were non pathogenic strains.

All the selected rhizobacteria found tolerant to pesticides viz. methomyl, imidacloprid and carbendazim, to at least $0.1 \%$ concentration (data not shown). Tolerance of selected species of Pseudomonas and Bacillus to methomyl, carbendazim and imidacloprid at varying concentrations was probably due to ability of the bacteria to metabolise methomyl, imidacloprid and carbendazim utilizing them as sole carbon source for growth in carbon deficient minimal media (Sarat \& Barathi, 2013; Roy \& Das, 2017). This might be helpful for them to sustain in pesticide-stress toxic condition due to increase in metabolic potential. Castillo et al. (2011) reported similar observations in Azotobacter, where the bacteria utilized the pesticide endosulfan as a sole source of $\mathrm{C}, \mathrm{S}$ and $\mathrm{P}$ for their growth and other activities. Similar tolerance to a number of pesticides was reported in PGPR Mesorhizobium (Ahemad \& Khan, 2012).

Previously, the bacterial isolates exhibited metabolic activities which serve as antagonistic and plant growth promoting traits to be classified as PGPR. The bioagents were found to produce non-volatile anti fungal compounds, volatile $\mathrm{HCN}$, cell wall degrading enzymes (CWDE) like endoglucanase, pectinase, chitinase, siderophores, plant growth promoting IAA and solubilised insoluble phosphates like Trichloro acetic acid (TCA) even in presence of pesticides (Bandopadhyay et al., 2018).

\subsection{In vitro antagonistic activity of rhizobacteria}

Assay for in vitro antagonistic activity of rhizobacteria against the pathogen $M$. phaseolina strain $\mathrm{m} 2$, showed inhibition of pathogen by all the bacterial isolates. Amongst them, Pseudomonas aeruginosa (Tn 6) exhibited maximum antagonistic activity against pathogen in vitro up to $63 \%$ (Figure 1). From this search, it was observed that virulence of the fungal pathogen $\mathrm{m} 2$ was affected by application of pesticide tolerant PGPRs. All the bacterial isolates viz. B. cereus, B. safensis, Tn-1, Tn-4, D1 and Tn 6 produced volatile and non volatile anti fungal compounds, $\mathrm{HCN}$, cell wall degrading enzymes (CWDE) and siderophores. Therefore the pathogen growth could have been suppressed in vitro through the mechanism of antibiosis. Species of Bacillus is known to produce peptide antibiotics like bulbiformin, bacitracin, gramicidin, subtilin, polymyxin, tyrocidine, etc. which could be responsible for antagonism (Gulhane et al., 2014). Several species of Fluorescent Pseudomonads are known to produce antibiotics like pyoluteorin, pyrrolnitrin, phenazine-1-carboxylic acid or 2,4-diacetylphloroglucinol which have antifungal activity (Muller et al., 2018). The bacteria produced hydrolytic enzymes endoglucanase, pectinase and chitinase

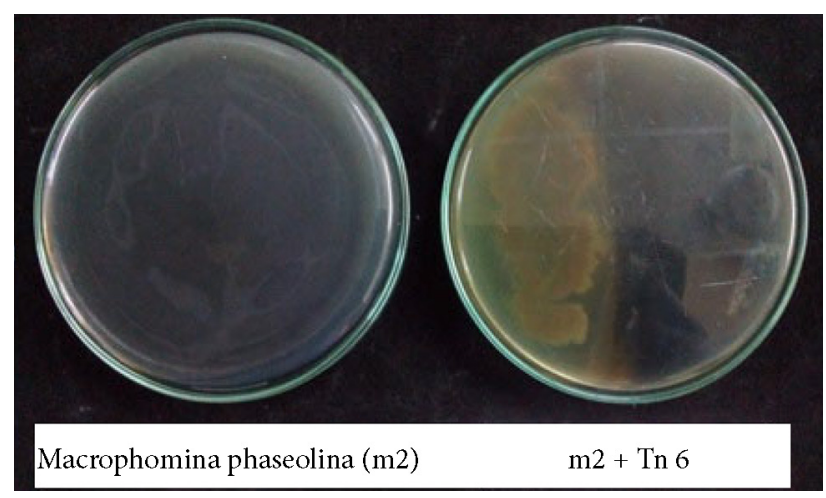

Figure 1. In vitro inhibition of pathogen $\mathrm{m} 2$ by Pseudomonas aeruginosa (Tn 6) 
which could have lysed the chitin containing fungal cell wall, there by expressing fungistatic and mycolytic activity. Siderophores produced by the bacterial isolates probably have sequestered micro elements from the medium, thus inhibiting the fungal growth. Moreover, siderophores have antibiotic properties which might be inhibitory to the fungi.

\subsection{Evaluation of rhizobacteria for disease control and plant growth promotion in field}

Field evaluation of the bacterial bioagents for control of Macrophomina diseases in cowpea, showed significant percent of disease control up to $77.8 \%$ by Tn 6 and Tn-4, followed by B. cereus $72.3 \%$ (Figure 2). Root length increased maximum in CMC treated plants of average $17.24 \mathrm{~cm}$. Among bio-agents Tn 6 increased maximum root length $10.58 \mathrm{~cm}$ followed by $B$. cereus $10.20 \mathrm{~cm}$ (Figure 3). Tn 6 increased maximum shoot length $32.14 \mathrm{~cm}$ followed by Tn-1 $26.84 \mathrm{~cm}$ in host plant (Figure 3). Average nodule count per plant was found maximum in Tn-4 treated plants 12.6 , followed by $B$. safensis 11 and 10.8 in Tn 6 (Figure 4). Highest average biomass per plant $1.7 \mathrm{gm}$ was obtained from Tn-1 and Tn 6 treated plants and next in order was B. cereus 1.45 gm (Figure 5). Yield per plant was highest in Tn $638.3 \mathrm{gm}$, followed by Tn-1 $30.7 \mathrm{gm}$ and B. safensis $29.5 \mathrm{gm}$ (Figure 6).

Field evaluation of the bacteria exposed significant control of Macrophomina diseases in cowpea. Highest BE conferred by Tn 6 , followed by Tn-4, and B. cereus.

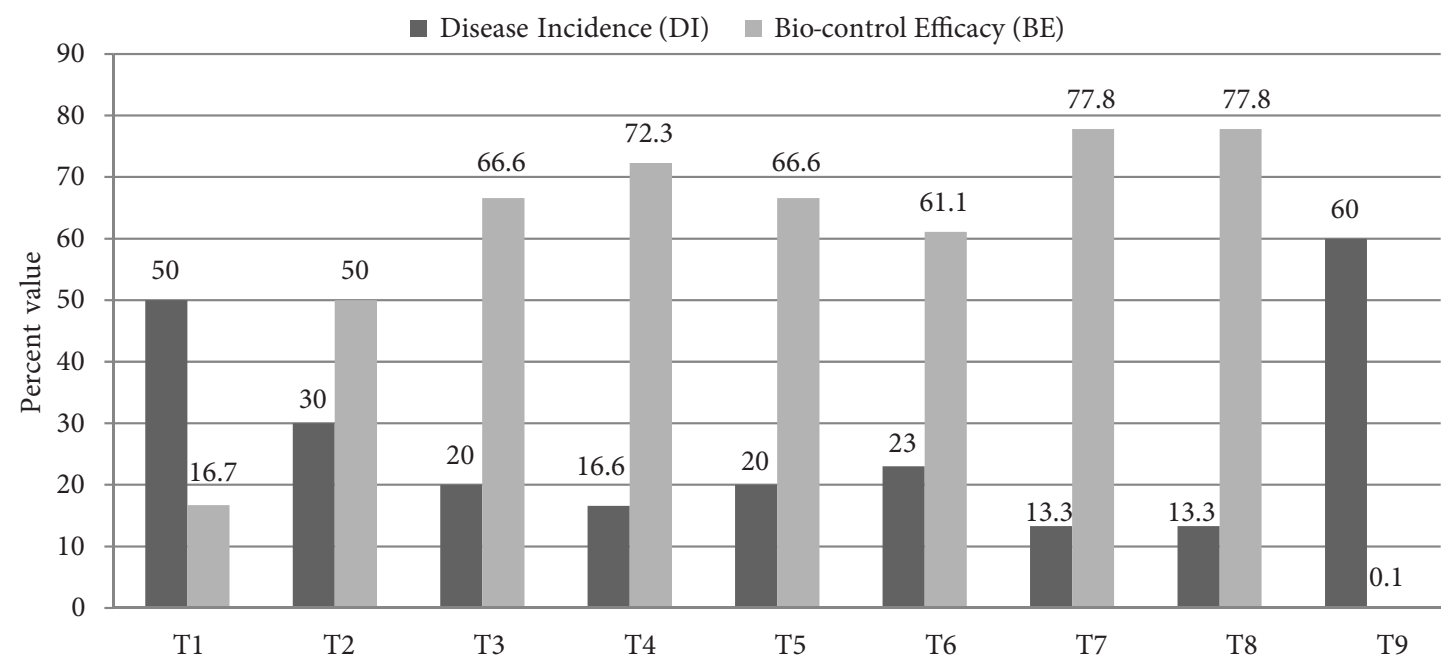

Treatments: T1 Control (hydropriming), T2 Control (CMC only), T3 (D1 + CMC + P), T4 (B. cereus + CMC + P), T5 $($ B. safensis + CMC + P), T6 $(\mathrm{Tn}-1+\mathrm{CMC}+\mathrm{P}), \mathrm{T} 7(\mathrm{Tn}-4+\mathrm{CMC}+\mathrm{P}), \mathrm{T} 8(\mathrm{Tn} 6+\mathrm{CMC}+\mathrm{P})$, T9 (Macrophomina phaseolina $\mathrm{m} 2$ ). $\mathrm{P}$ = Pathogen (Macrophomina phaseolina).

Figure 2. Field evaluation of rhizobacteria on Disease incidence (DI) and Bio-control efficacy (BE) in Cowpea

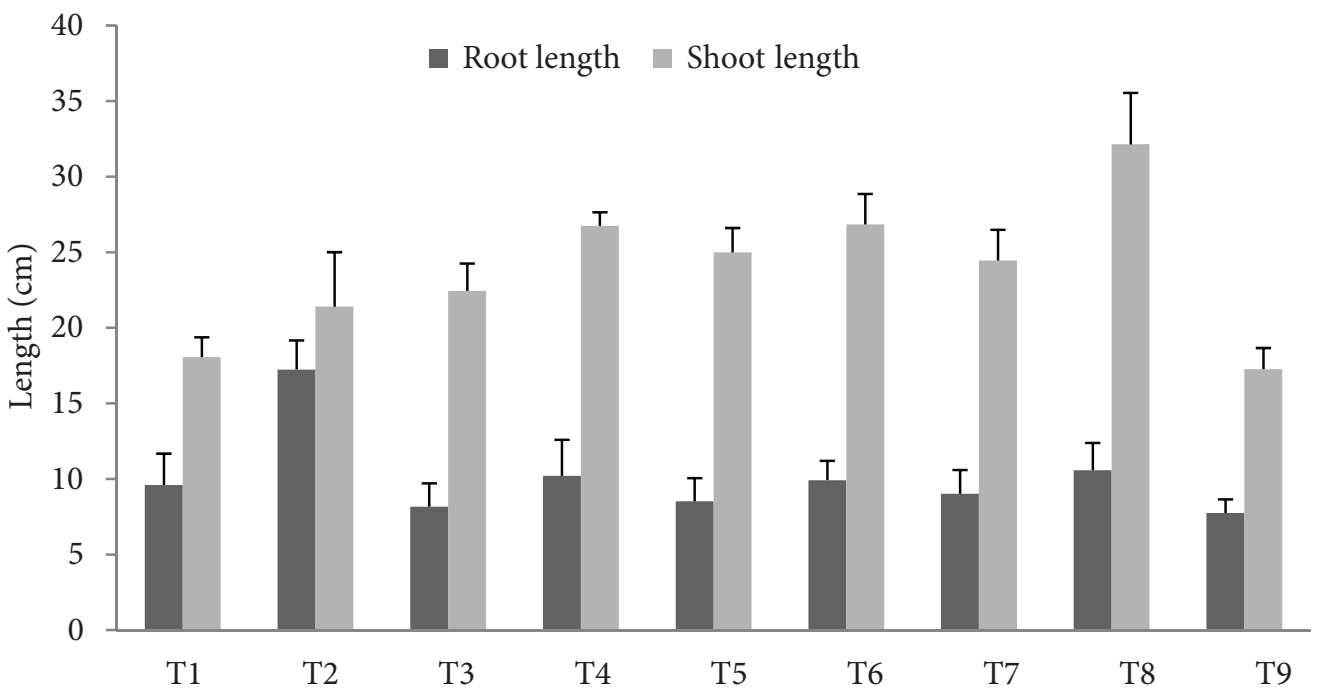

Treatments: T1 Control (hydropriming), T2 Control (CMC only), T3 (D1 + CMC + P), T4 (B. cereus + CMC + P), T5 (B. safensis + CMC + P), T6 (Tn-1 + CMC + P), T7 (Tn-4 + CMC + P), T8 (Tn6 + CMC + P), T9 (Macrophomina phaseolina $\mathrm{m} 2$ ). $\mathrm{P}$ = Pathogen (Macrophomina phaseolina).

Figure 3. Effect of rhizobacteria on average root and shoot length per host plant in field 


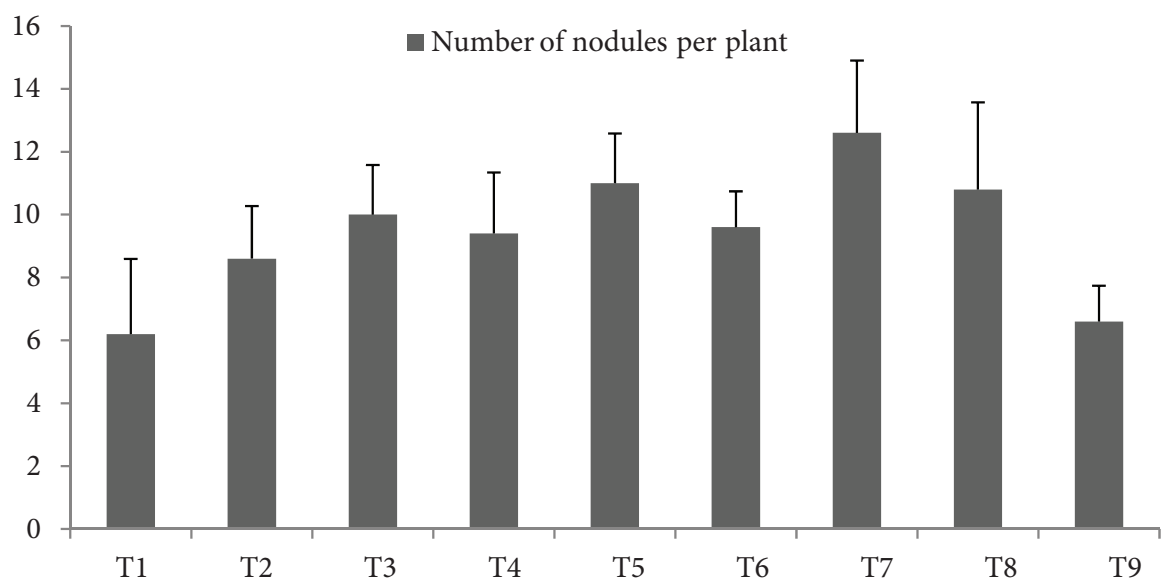

Treatments: T1 Control (hydropriming), T2 Control (CMC only), T3 (D1 + CMC + P), T4 (B. cereus + CMC + P), T5 (B. safensis + CMC + P), T6 (Tn-1 + CMC + P), T7 $($ Tn $-4+\mathrm{CMC}+\mathrm{P}), \mathrm{T} 8(\mathrm{Tn} 6+\mathrm{CMC}+\mathrm{P})$, T9 (Macrophomina phaseolina m2). $\mathrm{P}=$ Pathogen (Macrophomina phaseolina).

Figure 4. Effect of rhizobacteria on average nodule count per host plant in field

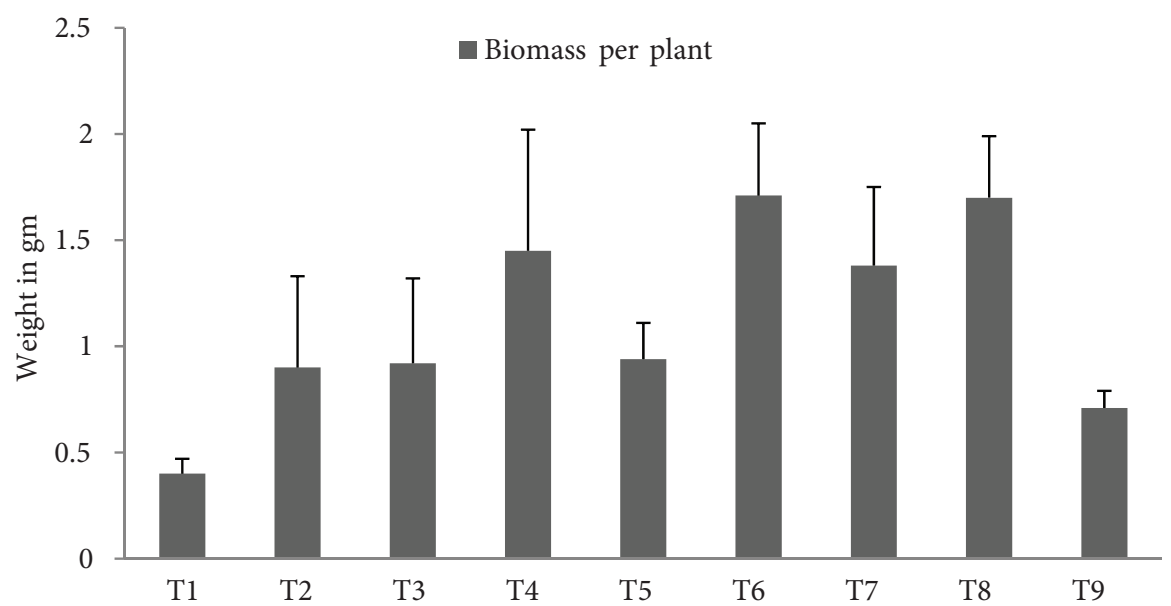

Treatments: T1 Control (hydropriming), T2 Control (CMC only), T3 (D1 + CMC + P), T4 (B. cereus + CMC + P), T5 (B. safensis + CMC + P), T6 (Tn-1 + CMC + P), T7 $($ Tn $-4+\mathrm{CMC}+\mathrm{P}), \mathrm{T} 8(\mathrm{Tn} 6+\mathrm{CMC}+\mathrm{P})$, T9 (Macrophomina phaseolina m2). P = Pathogen (Macrophomina phaseolina).

Figure 5. Effect of rhizobacteria on average biomass per host plant in field

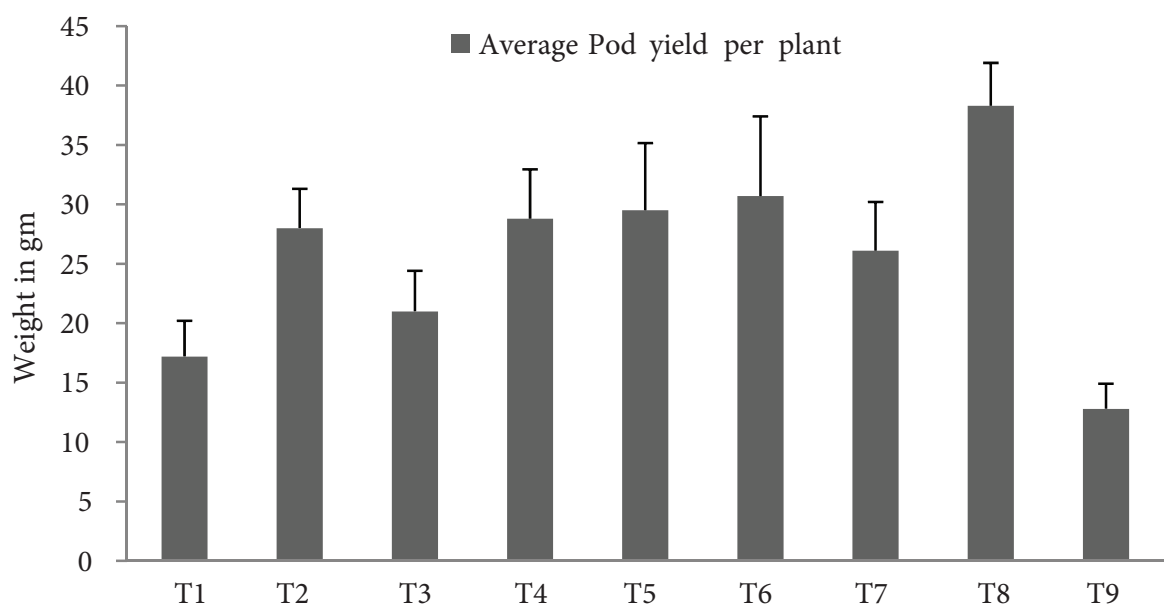

Treatments: T1 Control (hydropriming), T2 Control (CMC only), T3 (D1 + CMC + P), T4 (B. cereus + CMC + P), T5 (B. safensis + CMC + P), T6 (Tn-1 + CMC + P), T7 (Tn-4 + CMC + P), T8 (Tn6 + CMC + P), T9 (Macrophomina phaseolina $\mathrm{m} 2$ ). $\mathrm{P}=$ Pathogen (Macrophomina phaseolina).

Figure 6. Effect of rhizobacteria on pod yield per plant in field 
This result is attributed to owing of several antagonistic biocontrol traits like production of pathogen-deterrent compounds, including polysaccharides, proteins, antibiotics and siderophores against the pathogen by the biocontrol agents (BCAs). The investigation also revealed that Tn-1, Tn-4, Tn 6, B. safensis and B. cereus improved root length, shoot length, nodule count, plant biomass as well as yield per cowpea plant compared to treatments without bioagents. Thus production of plant growth regulators like IAA, ACC deaminase (Khan et al., 2016), supply of siderophore sequestered iron and other micro nutrients to the plant, and solubilisation of insoluble phosphates by rhizobacteria increased plant vigour. Moreover, nodule counts were also enhanced by the PGPR which in turn probably increased the activity of nitrogen fixation in the soil by the root nodule inhabiting Rhizobium. This could have also boosted plant growth in field soils. The rhizobacteria could improve plant height as well as biomass of cowpea, hence contesting with other deleterious micro-flora or acting synergistic with other beneficial microbes present in the root zone under field condition. Moreover, endospore forming ability by Bacillus facilitates in effective bio-fertilizer formulation thus enabling them to endure in an ample range of environmental conditions (Perez-Garcia et al., 2011).

\subsection{Induced systemic resistance in host plants}

Highest PAL activity was exhibited in Tn 6 as $1.02 \mu$ Moles/ $\mathrm{ml} / \mathrm{min}, \mathrm{PPO}$ activity exhibited in Tn- 1 as $1.39 \mu \mathrm{Moles} / \mathrm{ml} /$ min, chitinase activity in Tn-4 $0.745 \mu$ Moles $/ \mathrm{ml} / \mathrm{min}$ and relative activity of PO in Tn 6 was 400 followed by B. cereus 350. (Figures 7, 8, 9 and 10). Challenge inoculation

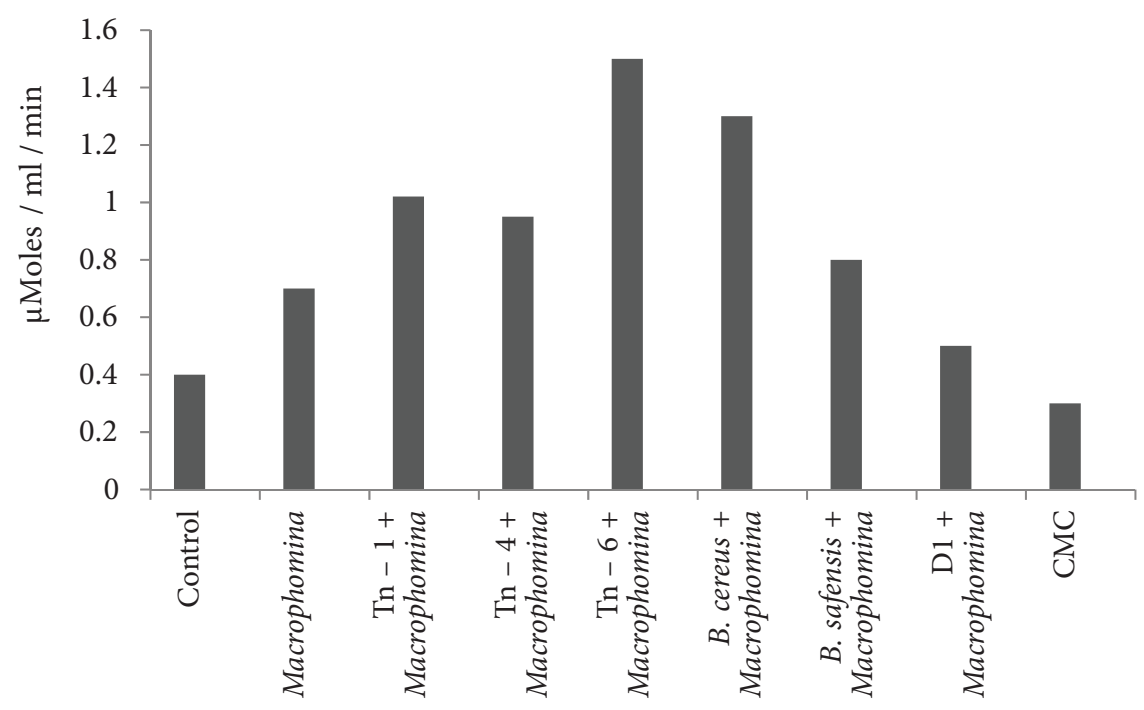

Figure 7. Graphical representation of phenylalanine ammonia lyase (PAL) activity in rhizobacteria treated plant

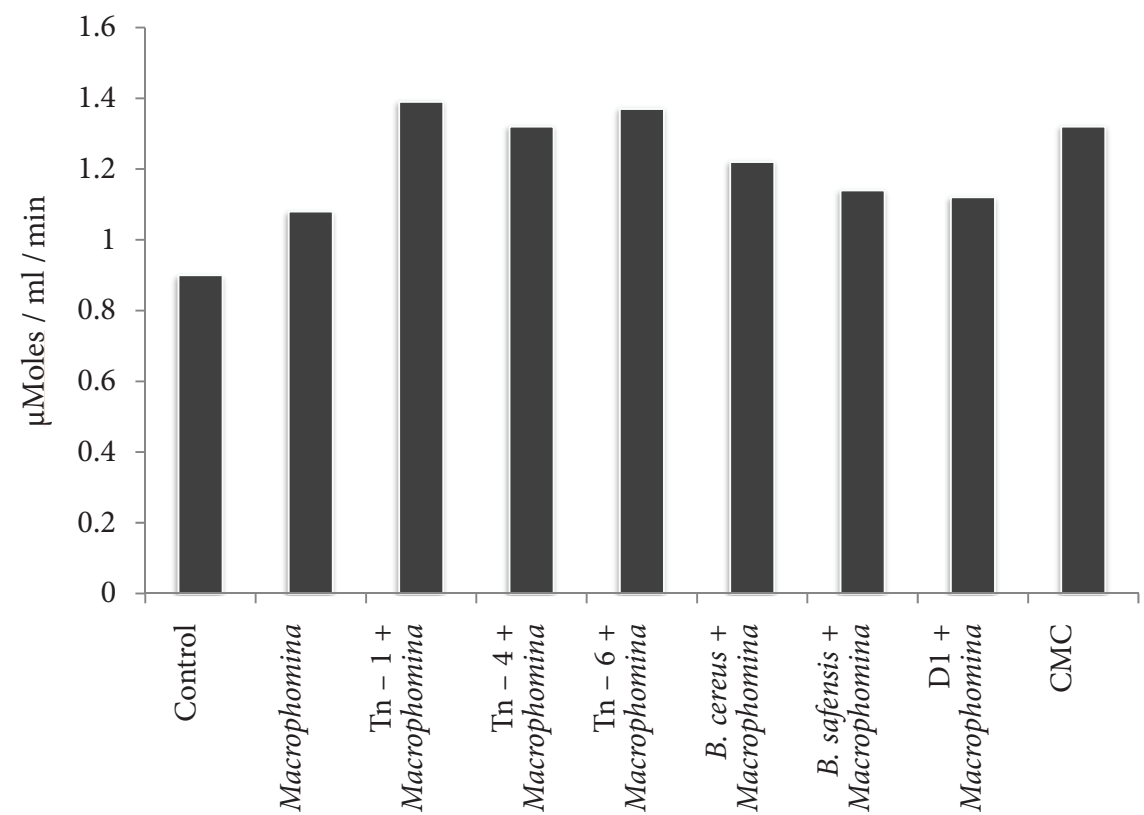

Figure 8. Graphical representation of polyphenol oxidase (PPO) activity in rhizobacteria treated plant 
with pathogen showed higher PAL, PPO, Chitinase and PO enzyme activity in Tn-1, Tn-4, Tn6 and Bacillus cereus treated plants compared to control. According to Karthikeyan et al. (2005), expression of defense related enzymes viz., peroxidase (PO), phenylalanine ammonia lyase (PAL) and polyphenol oxidase (PPO) induce enhancement of total phenolics and lignin in plant tissues. PAL is an important enzyme associated with phenylpropanoid pathway responsible for synthesis of phytoalexins, flavonoids and lignins having defensive action over pathogen infection (Daayf et al., 1997). Tn 6 treated plants produced maximum PAL enzyme correlating with highest disease resistance against pathogen. PPO is involved in biosynthesis of lignin and other oxidative phenols. Enhancement of lignification is a defensive mechanism of host plant to hinder the pathogenic entry through the cell wall. In the present study, the highest level of PPO was recorded in Tn-1 treated plants. PO participates defensive activities due to phenolic oxidation and lignification in host tissues against pathogens. Some POs have also been identified as pathogenesis related (PR) proteins (Ishige et al., 1993). Increased level of chitinase was also recorded after treatment with $B$. cereus $\mathrm{Tn}-4$ in challenged plants. Chitinase is a defense enzyme which degrade the fungal pathogenic cell wall component. Maximum reduction in disease incidence was noticed in the plants treated with the Pseudomonas aeruginosa (Tn 6), Bacillus cereus including Tn-4, and Pseudomonas donghuensis Tn-1 due to the elicitation of phytoalexin and induction of systemic resistance (ISR) in host plant (Kloepper et al., 2004; Egamberdieva et al., 2017). Many rhizospheric bacteria including Bacillus

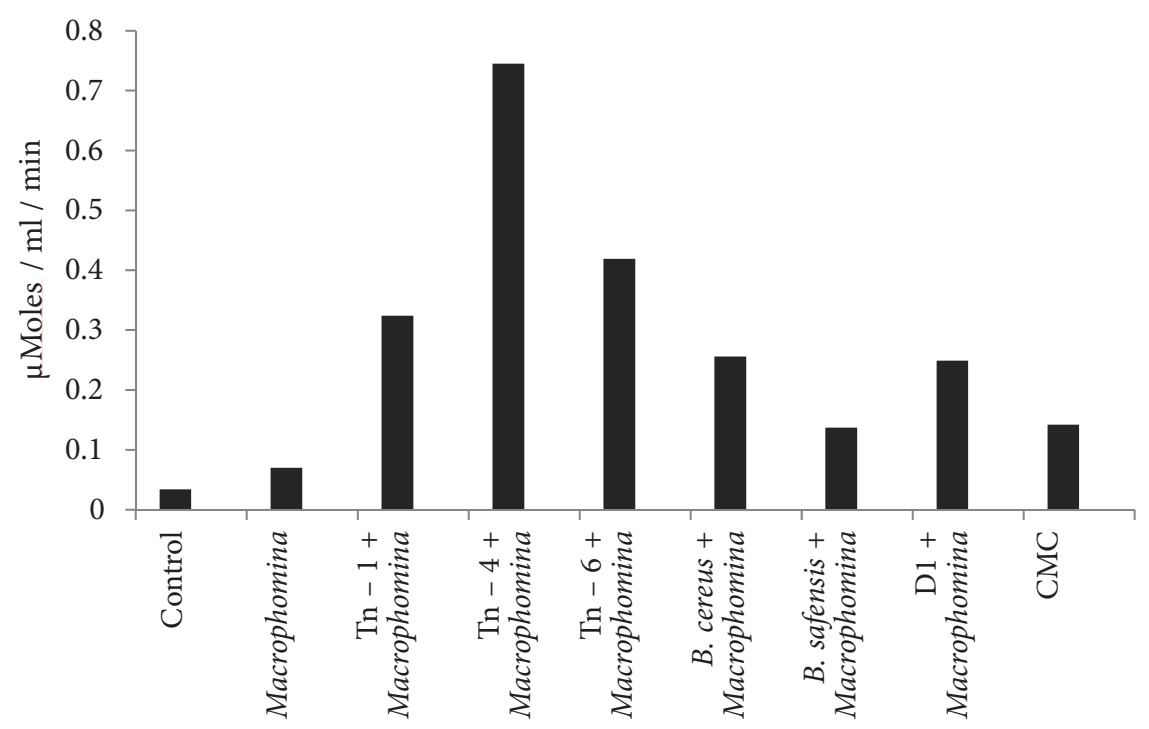

Figure 9. Graphical representation of chitinase activity in rhizobacteria treated plant

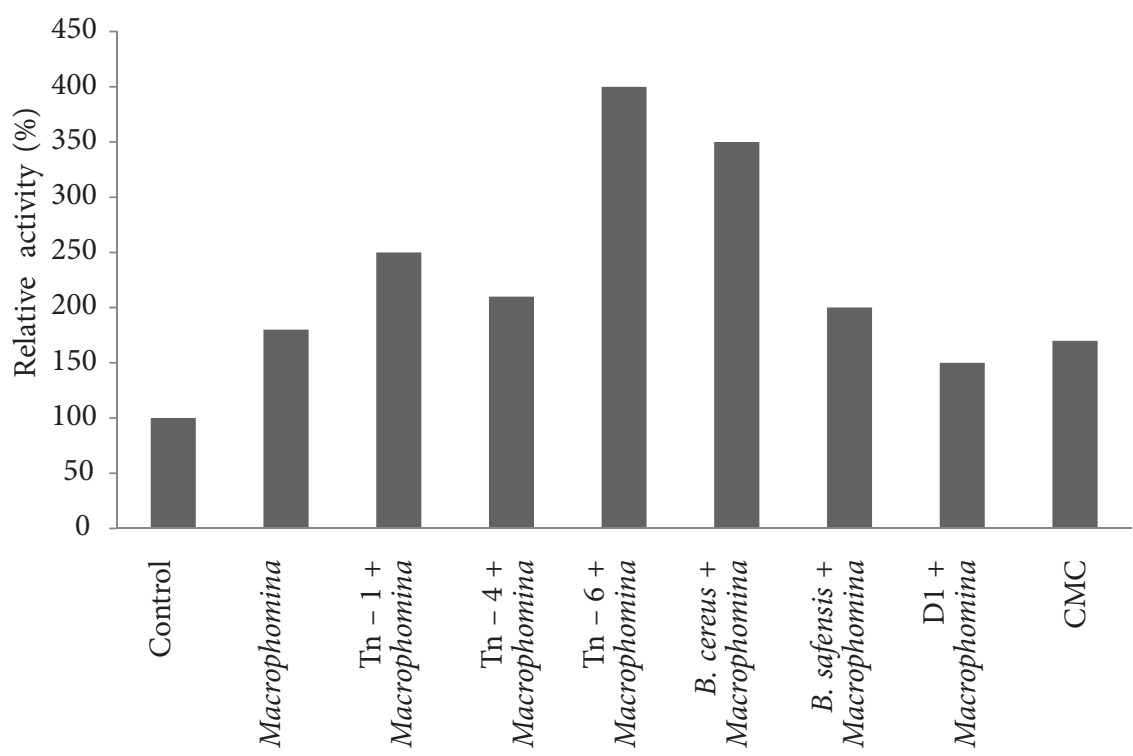

Figure 10. Graphical representation of peroxidise PO activity in rhizobacteria treated plant 
and Pseudomonas have been reported to elicit such defense activities for a prolonged time at a higher level in host plants (Umamaheswari et al., 2009; Lyu et al., 2019).

Plants treated with fluorescent pseudomonad could also be protected from infection by inducing SAR i.e. systemic acquired resistance (Van Loon et al., 1998). Unlike Pseudomonas, Bacillus sp. triggers ISR pathway within plants through both ethylene and jasmonate mediated paths (Santoyo et al., 2012). In the current study, maximum decrease in disease occurrence has been perceived in plants inoculated with Pseudomonads and three strains of $B$. cereus, possibly due to the stimulation of defense related enzyme against $M$. phaseolina. Plants treated with bioagents resulted in increase of $\mathrm{PR}$ protein contents.

Thus, reduction of disease incidence, induction of systemic resistance and growth promotion in Vigna unguiculata with fluorescent Pseudomonas and Bacillus is evident from this study. Similar results were reported by Ricci et al., in 2019. Furthermore, the pesticide tolerant rhizobacterial strains can also be used efficiently for bio- remediation of pesticide infested toxic field soil. These selected PGPRs have heavy metal chelating abilities through production of siderophores, so can also be harnessed for bioremediation of toxic metals like arsenic from highly contaminated soil.

\section{Conclusions}

Due to unremitting use of chemical pesticides, farmer's field is previously envenomed with huge amount of pesticide residues. Most fungicides have short-lived effect and need repeated applications thus exposing to several doses of fungicides and hence increasing the risk of residues gathering up in the environment. Biological control usually takes longer time to activate to reduce diseases, but also its effect lasts longer. Most bio-control agents are harmless to naturally occurring organisms, thus are safe. More over the selected pesticide tolerant bio-agents may also be potential for biodegradation of persistent pesticides prevailing in the soil. Therefore search for proficient native bio-inoculants having better action of disease suppression and plant growth augmentation in pesticide swamped soil is vital. Therefore, from the current study it can be envisioned that pesticide tolerant PGPR viz., Bacillus cereus, Pseudomonas donghuensis and Pseudomonas aeruginosa have disease control and plant growth promoting properties on Vigna unguiculata.

Thus, with multifunctional PGPR activities and for multiple benefits of pathogen suppression sustaining in varied pesticides, plant nutrient supply and growth promotion, these indigenous bio-inoculants have enormous potential in future broadening the spectrum of PGPR available for field application. Therefore, in future, these may be exploited as suitable microbial bio-pesticide and biofertilizer for disease management, plant growth promotion as well as soil bio-remediation for sustainable, low cost eco-friendly agriculture.

\section{Acknowledgements}

The work was financially supported by Department of Science and Technology (West Bengal), India [Memo no. 757 (Sanc)/ST/P/S\&T/1G-15/2014].

\section{Conflict of interests}

All authors declare that there are no conflict of interest in the present investigation.

\section{References}

Ahemad, M., \& Khan, S. M. (2012). Effects of pesticides on plant growth promoting traits of Mesorhizobium strain MRC4. Journal of the Saudi Society of Agricultural Sciences, 11(1), 63-71. https://doi.org/10.1016/j.jssas.2011.10.001

Ahlawat, I. P. S., \& Shivakumar, B. G. (2005). Kharif pulses. In Dr. R. Prasad (Ed.), Textbook of field crops production. Indian Council of Agricultural Research, New Delhi, India.

Akram, W., Anjum, T., Ali, B., \& Ahmad, A. (2013). Screening of native Bacillus strains to induce systemic resistance in tomato plants against Fusarium wilt in split root system and its field applications. International Journal of Agriculture and Biology, 15(6), 1289-1294.

Ambalavanan, S., \& Selvaraj, T. (2013). Induction of defense related enzymes in anthurium by application of fungal and bacterial bio-control agents against Colletotricum gloeosporiodes. International Journal of Current Microbiology and Applied Sciences, 2(12), 661-670.

Bandopadhyay, A., Bandopadhyay, A. K., Majumdar, M., \& Samajpati, N. (2006). Evaluation of antagonistic potential of some rhizosphere fungi and PGPR against Macrophomina phaseolina inciting disease complex in jute. Journal of Basic and Applied Mycology, 5(1\&II), 8286.

Bandopadhyay, A., Roy, T., \& Das, N. (2018). Isolation of some soil bacteria showing potentiality for disease control, growth enhancement and pesticide degradation in Vigna unguiculata L. Plant Archives, 18 (Special Issue ICAAAS-2018), 7988.

Boeckx, T., Winters, A. L., Webb, K. J., \& Kingston-Smith, A. H. (2015). Polyphenol oxidase in leaves: Is there any significance to the chloroplastic localization? Journal of Experimental Botany, 66(12), 3571-3579. https://doi.org/10.1093/jxb/erv141

Bradford, M. M. (1976). A rapid and sensitive method for the quantitation of microgram quantities of protein utilizing the principle of protein-dye binding. Annals of Biochemistry, $72(1), 248-254$.

https://doi.org/10.1016/0003-2697(76)90527-3

Carvalho, F. P. (2017). Pesticides, environment, and food safety. Food and Energy Security, 6(2), 48-60. https://doi.org/10.1002/fes3.108

Castillo, J. M., Casas, J., \& Romero, E. (2011). Isolation of an endosulfan degrading bacterium from a coffee farm soil: Persistence and inhibitory effect on its biological functions. Science of the Total Environment, 412, 20-27.

https://doi.org/10.1016/j.scitotenv.2011.09.062

Cavalier-Smith, T. (2005). Economy, speed and size matter: Evolutionary forces driving nuclear genome miniaturization and expansion. Annals of Botany, 95(1), 147-175. https://doi.org/10.1093/aob/mci010

Chevalier, A. (1964). Cowpea in Africa. Revue de Botonique Appliqucectd. Agriculture Tropicale, 24, 128. 
Daayf, F., Schmitt, A., \& Bélanger, R. R. (1997). Evidence of phytoalexins in cucumber leaves infected with powdery mildew following treatment with leaf extracts of Reynoutria sachalinensis. Plant Physiology, 113(3), 719-727.

https://doi.org/10.1104/pp.113.3.719

Davis, D. W., Oelke, E. A., Oplinger, E. S., Doll, J. D., Hanso, C. V., \& Putnam, D. H. (2000). Alternative field crops \manual. https://hort.purdue.edu/newcrop/afcm/cowpea.html

Egamberdieva, D., Davranov, K., Wirth, S., Hashem, A., \& Abd, E. A. (2017). Impact of soil salinity on the plantgrowth- promoting and biological control abilities of root associated bacteria. Saudi Journal of Biological Sciences, 24(7), 1601-1608. https://doi.org/10.1016/j.sjbs.2017.07.004

Fatima, S., \& Anjum, T. (2017). Identification of a potential ISR determinant from Pseudomonas aeruginosa PM12 against Fusarium wilt in tomato. Frontiers in Plant Science, 8, 848. https://doi.org/10.3389/fpls.2017.00848

Gulhane, P., Ashok, A., Gomashe, V., \& Sneha, L. (2014). Optimization of bacitracin production from Bacillus licheniformis NCIM 2536. International Journal of Current Microbiology and Applied Sciences, 3(9), 819-829.

Heard, M. S., Baas, J., Dorne, J. L., J.-L., Lahive, E., Robinson, A. G., Rortais, A., Spurgeon, D. J., Svendsen, C., \& Hesketh, H. (2017). Comparative toxicity of pesticides and environmental contaminants in bees: Are honey bees a useful proxy for wild bee species? Science of the Total Environment, 578, 357-365. https://doi.org/10.1016/j.scitotenv.2016.10.180

Ishige, F., Mori, H., Yamazaki, K. I., \& Imaseki, H. (1993). Cloning of a complementary DNA that encodes an acidic chitinase which is induced by ethylene and expression of the corresponding gene. Plant and Cell Physiology, 34, 103-111.

Jiang, Y., Sheng, X. F., Qian, M., \& Wang, Q. Y. (2008). Isolation and characterization of a heavy metal-resistant Burkholderia sp. from heavy metal-contaminated paddy field soil and its potential in promoting plant growth and heavy metal accumulation in metal-polluted soil. Chemosphere, 72(2), 157164. https://doi.org/10.1016/j.chemosphere.2008.02.006

Johnson, L. F., \& Curl, E. A. (1972). Methods for research on the ecology of soil-borne plant pathogens. Burgess Publishing Company.

Karthikeyan, M., Bhaskaran, R., Radhika, K., Mathiyazhagan, S., Jayakumar, V., Sandosskumar, R., \& Velazhahan, R. (2005). Endophytic Pseudomonas fluorescens Endo2 and Endo35 induce resistance in black gram (Vigna mungo L. Hepper) to the pathogen Macrophomina phaseolina. Journal of Plant Interactions, 1(3), 135-143. https://doi.org/10.1080/17429140600997309

Khan, A. L., Halo, B. A., Elyassi, A., Ali, S., A-Hosni, K., Hussain, J., Al-Harrasi, A., \& Lee, I. J. (2016). Indole acetic acid and ACC deaminase from endophytic bacteria improves the growth of Solannum lycopersicum. Electronic Journal of Biotechnology, 21, 58-64. https://doi.org/10.1016/j.ejbt.2016.02.001

Khan, M. S., Zaidi, A., Wani, P. A., \& Oves, M. (2009). Role of plant growth promoting rhizobacteria in theremediation of metal contaminated soils. Environmental Chemistry Letters, 7, 119. https://doi.org/10.1007/s10311-008-0155-0

Kloepper, J. W. (1993). Plant growth promoting rhizobacteria as biological control agents. In F. B. Metting Jr. (Ed.), Soil microbial ecology (pp. 225-274). Marcel Dekker, Inc.

Kloepper, J. W., Ryu, C. M., \& Zhang, S. (2004). Induced systemic resistance and promotion of plant growth by Bacillus sp. Phytopathology, 94(11), 1259-1266.

https://doi.org/10.1094/PHYTO.2004.94.11.1259
Liu, K., Newman, M., McInroy, J. A., Hu, C. H., \& Kloepper, J. W. (2017). Selection and assessment of Plant Growth-Promoting Rhizobacteria (PGPR) for biological control of multiple plant diseases. Phytopathology, 107(8), 928-936. https://doi.org/10.1094/PHYTO-02-17-0051-R

Lyu, D., Backer, R., Robinson, W. G., \& Smith, D. L. (2019). Plant growth-promoting rhizobacteria for cannabis production: Yield, cannabinoid profile and disease resistance. Frontiers in Microbiology, 10, 1761.

https://doi.org/10.3389/fmicb.2019.01761

Muller, T., Ruppel, S., Behrendt, U., Lentzsch, P., \& Muller, M. E. H. (2018). Antagonistic potential of fluorescent pseudomonads colonizing wheat heads against mycotoxin producing Alternaria and Fusaria. Frontiers in Microbiology, 9, 2124. https://doi.org/10.3389/fmicb.2018.02124

Niewiadomska, A., \& Klama, J. (2005). Pesticide side effect on the symbiotic efficiency and nitrogenase activity of Rhizobiaceae bacteria family. Polish Journal of Microbiology, 54, 43-48.

Ngumbi, E., \& Kloepper, J. (2016). Bacterial-mediated drought tolerance: Current and future prospects. Applied Soil Ecology, 105, 109-125. https://doi.org/10.1016/j.apsoil.2016.04.009

Perez-Garcia, A., Romero, D., \& de Vicente, A. (2011). Plant protection and growth stimulation by microorganism: Biotechnological applications of Bacillus in agriculture. Current. Opinion in Biotechnology, 22(2), 187-193.

https://doi.org/10.1016/j.copbio.2010.12.003

Pütter, J. (1974). Peroxidases. In H. U. Bergmeyer (Ed.), Method of enzymatic analysis: Vol. 2 (2 $2^{\text {nd }}$ ed., pp. 685-690). Academic Press. https://doi.org/10.1016/B978-0-12-091302-2.50033-5

Ricci, E., Schwinghamer, T., Fan, D., Smith, D. L., \& Gravel, V. (2019). Growth promotion of greenhouse tomatoes with Pseudomonas sp. and Bacillus sp. biofilms and planktonic cells. Applied Soil Ecology, 138, 61-68. https://doi.org/10.1016/j.apsoil.2019.02.009

Roy, T., \& Das, N. (2017). Isolation, characterization and identification of two methomyl degrading bacteria from a pesticidetreated crop field in West Bengal, India. Microbiology, 86, 753-764. https://doi.org/10.1134/S0026261717060145

Roy, T., Bandopahyay, A., Sonawane, P., Majumdar, S., Mahapatra, N., Alam, S., \& Das, N. (2018). Bio-effective disease control and plant growth promotion in lentil by two pesticide degrading strains of Bacillus sp. Biological Control, 127, 55-63. https://doi.org/10.1016/j.biocontrol.2018.08.018

Saikia, J., Sarma, R. K., Dhandia, R., Yadav, A., Bharali, R., Gupta, V. K., \& Saikia, R. (2018). Alleviation of drought stress in pulse crops with ACC deaminase producing rhizobacteria isolated from acidic soil of Northeast India. Scientific Reports, 8, 3560. https://doi.org/10.1038/s41598-018-21921-w

Santoyo, G., Orozco-Mosqueda, M. D. C., \& Govindappa, M. (2012). Mechanisms of biocontrol and plant growth-promoting activity in soil bacterial species of Bacillus and Pseudomonas: A review. Biocontrol Science and Technology, 22(8), 855-872. https://doi.org/10.1080/09583157.2012.694413

Sarat, N., \& Barathi, S. (2013). Enrichment and isolation of endosulfan degrading microorganisms in cashew plantations of Kasargod district, Kerala. International Journal of ChemTech Research, 5(1), 06-14.

Shahgoli, H., \& Ahangar, A. G. (2014). Factors controlling degradation of pesticides in the soil Environment: A review. Agriculture Science Developments, 3, 273-278.

Shahid, M., \& Khan, M. S. (2017). Assessment of glyphosate and quizalofop mediated toxicity to greengram [Vigna radiata (L.) Wilczek], stress abatement and growth promotion by herbi- 
cide tolerant Bradyrhizobium and Pseudomonas species. International Journal of Current Microbiology and Applied Sciences, 6(12), 3001-16. https://doi.org/10.20546/ijcmas.2017.612.351

Singh, A. K., Bhatt, B. P., Sundaram, P. K., Kumar, S., Bahrati, R. C., Chandra, N. N., \& Rai, M. (2012). Study of site specific nutrients management of cowpea seed production and their effect on soil nutrient status. Journal of Agricultural Sciences, 4(10), 191-198. https://doi.org/10.5539/jas.v4n10p191

Sobariu, D. L., Fertu, D. I. T., Diaconu, M., Pavel, L.V., Hlihor, R. M., Drãgoi, E. N., Curteanu, S., Lenz, M., Corvini, P. F.-X., \& Gavrilescu, M. (2017). Rhizobacteria and plant symbiosis in heavy metal uptake and its implications for soil bioremediation. New Biotechnology, 39(Part A), 125-134. https://doi.org/10.1016/j.nbt.2016.09.002

Tiwari, A. K., \& Shivhare, A. K. (2016). Pulses in India: Retrospect and prospects (Publication NoDPD/Pub.1/Vol. 2/2016). http://dpd.gov.in/Book\%20Document\%20on\%20Pulses\%20 in\%20India\%20Retrospect\%20\&\%20Prospects.pdf
Umamaheswari, C., Sankaralingam, A., \& Nallathambi, P. (2009). Induced systemic resistance in watermelon by biocontrol agents against Alternaria alternata. Archives of Phytopathology and Plant Protection, 42(12), 1187-1195. https://doi.org/10.1080/03235400701652383

Wu, M., Li, G., Chen, X., Liu, J., Liu, M., Jiang, Ch., \& Li, Z. (2018). Rational dose of insecticide chlorantraniliprole displays a transient impact on the microbial metabolic functions and bacterial community in a silty-loam paddy soil. Science of the Total Environment, 616, 236-244. https://doi.org/10.1016/j.scitotenv.2017.11.012

Van Loon, L. C., Bakker, P. A. H. M., \& Pieterse, C. M. J. (1998). Systemic resistance induced by rhizosphere bacteria. Annual Review of Phytopathology, 36, 453-448. https://doi.org/10.1146/annurev.phyto.36.1.453

Yan, Q., \& Fong, S. S. (2015). Bacterial chitinase: Nature and perspectives for sustainable bioproduction. Bioresources and Bioprocessing, 2(1), 1-9.

https://doi.org/10.1186/s40643-015-0057-5 